\title{
WILEY

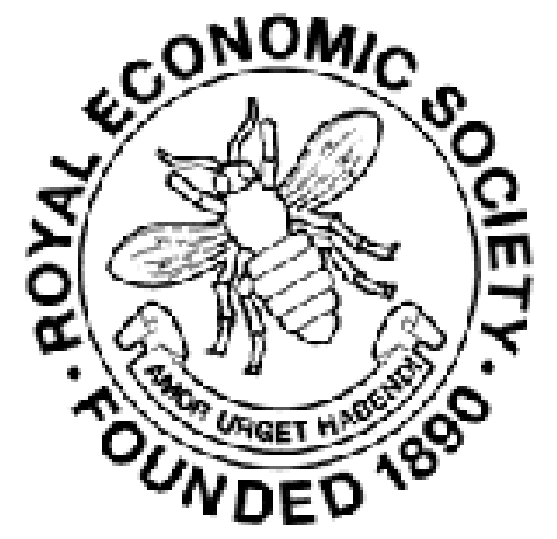

The Rural Industries Round Oxford: A Survey made on behalf of the Institute for Research into Agricultural Economics, University of Oxford. by K. S. Woods

Review by: Reginald Lennard

The Economic Journal, Vol. 32, No. 125 (Mar., 1922), pp. 110-113

Published by: Wiley on behalf of the Royal Economic Society

Stable URL: http://www.jstor.org/stable/2223127

Accessed: 24/12/2014 01:10

Your use of the JSTOR archive indicates your acceptance of the Terms \& Conditions of Use, available at http://www.jstor.org/page/info/about/policies/terms.jsp

JSTOR is a not-for-profit service that helps scholars, researchers, and students discover, use, and build upon a wide range of content in a trusted digital archive. We use information technology and tools to increase productivity and facilitate new forms of scholarship. For more information about JSTOR, please contact support@jstor.org.

Wiley and Royal Economic Society are collaborating with JSTOR to digitize, preserve and extend access to The Economic Journal. 
The Rural Industries round Oxford: A Survey made on behalf of the Institute for Research into Agricultural Economics, University of Oxford. By K. S. Woods. (Oxford : Clarendon Press, 1921. Pp. 180.) Price 7s. 6d.

This is a very useful supplement to the surveys of agriculture in Oxfordshire and Berkshire by Mr. John Orr and the account of Allotments and Small Holdings in Oxfordshire by Mr. A. W. Ashby which have already been published under the auspices of the Oxford Institute. It deals with the area within thirty miles of Oxford and refers to the period from March 1919 to March 1920. The book is divided into two parts-the first containing a general discussion of the economics of rural industries with a good deal of information about certain trades (e.g. farriery), and the second consisting of detailed reports on three groups of industries: viz. (i) the woodland industries (divided into the underwood trades, such as those which make rakes, besoms and hurdles, and, on the other hand, the timber industries, especially chair-leg turnery and chair-making); (ii) osier cultivation and willow basket-making; and (iii) " needlework and similar industries," of which the chief is the glove-making of Woodstock and its neighbourhood.

On the whole Miss Woods has done her work very well indeed, and it is practically pioneer work. In the general discussion of problems an admirable judgment is shown, and this is especially commendable because the subject of rural industries has often been a playground for well-meaning but sentimental faddists. Miss Woods has a keen eye for possibilities of development and for the economic factors upon which such possibilities depend; but she also has a sane appreciation of the dangers involved in ill-considered encouragement of rural industries (pp. 56-58, 67-68). Take, for example, her remark: "There is nothing more pathetic than the type of begging which is covered by the attempt to sell what is not really wanted, and to encourage this type of work is not charity." Defects are criticised without bias. The harm done to woodland industries by game and through the neglect of coppices and "gullies" by some of the landlords is duly noted (pp. 84-88), but Miss Woods also tells us "it is not realised by the turners, for whom the price of wood has doubled, how heavy the landlord's expenses have become, in taxation as well as in labour" (p. 109). On the one hand, we read of the high wages earned by blind basket-makers in a London factory (p. 129); on the other, of the scorn shown by professional basket-makers 
for " the poor work which was turned out from some of the hospitals where amateur teachers were relied upon" (p. 133). The helpful activities of Trade Unions and Women's Institutes are referred to with discrimination.

In the survey of particular industries, perhaps the best thing is the description of the timber industries, especially chairmaking. Problems connected with the growth of the raw material and with labour, machinery, designing and transport, are all carefully considered. In regard to basket-making, however, the limits of the subject are not very well kept, and the discussion ranges outside the Oxford district and beyond purely rural conditions.

The wretched rates of pay before the War, of which Miss Woods gives many instances, and the continuance of poor pay in some cases, illustrate one of the least satisfactory sides of rural industry; and a striking example is given of the exploitation of child labour by parents (pp. 39, 161). A defect of far-reaching influence is the "deplorable lack of enterprise and of commercial ability in the villages and small towns" (p. 29), and we read that "there is scarcely any co-operative effort in putting local products on the market" (p. 30). But while this is gloomy, it obviously means that the possibilities of rural industry are not exhausted.

The book is stored with curious and interesting facts. It is odd to find these country workshops supplying distant markets - parts of chairs going to Lancashire (p. 107), hurdles to the north of England and Scotland (p. 100), and barrel hoops formerly to the West Indies for sugar barrels (p. 92). "Before the War," we read, " all the Courts of Europe were clothed on State occasions in Oxfordshire plush from Shutford or Banbury." "Brilliant patterns were shown of pieces sent to Turkey and Roumania" (p. 174). A bowl-turner, one of whose lathes has been in use for more than a century, sells his wares to up-to-date establishments such as Harrods and the Army and Navy Stores. Among evidences of the play of large economic forces it is good to be reminded of the effects of individual occurrences, as when we are told that the wholesale clothing industry in Oxford "sprang from a debt paid by a linen draper to a small shopkeeper in the form of a bale of linen, towards the end of the eighteenth century," because "out of this the shopkeeper's wife made a labourer's smock, which was soon bought by a passing farm labourer," and "she sold a succession of smocks, and so the industry was built up" (p. 149). 
A few criticisms must be made. At the time the survey was taken nearly all the industries dealt with were subject to powerful but temporary war-induced influences-shortage of labour or material, in some cases, but, more commonly, a booming demand, owing to absence of foreign competition and the accumulation of demands unsatisfied during the War. Miss Woods is fully alive to this fact, but it requires emphasis, because it would be unwise to frame policy on the assumption that these conditions are normal.

The plan of the book has one fault. It excludes the extractive industries-quarrying, brick-making and the like, so that (to take the Cherwell Valley alone) we are told nothing about the Portland cement works at Kirtlington, the quarry at Ardley, the brick and tile works at Deddington, or the ironstone works at Adderbury and King's Sutton. This is a pity, for these are thoroughly rural industries, and the problems of labour in extractive undertakings (e.g. the treatment of the problem of wet weather) often throw light on similar problems in agriculture. Thatching also is omitted, though it is really a distinct trade, and certainly no more a mere part of agriculture than hurdlemaking, which is dealt with.

One or two details, again, call for criticism. There are a few cases of "vain repetition." The figures on p. 83 do not really illustrate Miss Wood's point that "on estates far from the railway prices of underwood have fallen considerably." Perhaps there is a misprint here; but the figures as they stand are quite inconelusive. On p. 101 occurs the following statement: "The increase in the use of hay-making and other machinery was mentioned in this district as a cause of the decline in agricultural earnings from those of an earlier generation, having led to less employment at piece-rates during the harvest and less employment of women in the fields." Cited without comment, this opinion is most misleading. The number of labourers has declined, but the trend of earnings was to increase even before the War, though it is true there was a set-back after the Trade Union débâcle in the seventies. No doubt the ratio of extra earnings to wages has declined: perhaps the passage quoted is due to a misunderstanding of this fact. Or does it mean that there is now less opportunity of part-time agricultural work for persons engaged mainly in village industries-or, in other words, that there is less seasonal fluctuation in the demand for farm labour now than formerly?

A word must be said about Mr. Arthur Ashby's instructive 
and interesting preface. Mr. Ashby gets down at once to fundamentals, pointing out that " the use of oil-fuel and the improvement of the internal-combustion engine has to a small extent changed the conditions of industrial production" (p. 7), that the change is " altogether in favour of the small establishment," and that in transport the motor lorry may bring similar developments (p. 8).

Reginald Lennard

Kiangsi Native Trade and its Taxation. By Stanley Wright. (Shanghai : The Chinese Customs Service. Pp. $203+$ II, with 2 Appendices.)

THE person who takes up this book expecting to find a practical application of Adam Smith's classical canons of taxation to an Eastern country will receive a rude shock. The system, such as it is, in force in Kiangsi, China, breaks every known rule of taxation for which economists have fought over a long period of years.

The Province of Kiangsi has an area of 69,498 square miles, and, according to the most recent census, the population is $14 \frac{1}{2}$ millions, so it is a fairly representative province to take for the purpose of investigating taxation in China. The question of internal trade taxation in that country is one on which much has been written in a general way, but little attempt has ever been made to isolate a province and to study in detail either the methods of trade taxation offices within its confines or their influence on the trades taxed. This book is therefore very welcome.

The Chinese seem to look upon trade as an inexhaustible reservoir into which innumerable hands may dip for revenue. Less than a century ago Kiangsi trade boasted only two taxing establishments, namely, the Native Customs for the PoyangYangtsze trade, and that for the traffic up and down the River Kan, but to-day the Kiangsi merchant has to reckon with seven or eight trade-taxing establishments, each spreading its tentacles out over a wide area. In the past, provided he paid the tax, plus certain non-official "squeezes," he was free to go his way, but now he is surrounded by difficulties too numerous to mention. The trader cannot move a single package of goods even for a short distance overland without encountering some form of taxgatherer. Custom is the guiding principle, and the Central No. 125.-VOL. XXXII. 